\title{
ReVISTA KINESIS
}

v. 36, n. 3, set-dez. 2018

\section{EDITORIAL}

\section{Elenor Kunz}

Editor

Temos a satisfação e a alegria de veicular por esse meio eletrônico nosso terceiro e último número da Revista Kinesis para o ano de 2018. Foi um ano bastante trabalhoso para a equipe editorial, pois além do crescimento do número de artigos recebidos - contamos ainda com a carência de revisores para determinadas temáticas -, trabalhamos bastante, como já mencionamos no editorial passado, com o encaminhamento de nossa revista para a avalição no Indexador Lilacs. Até o momento ainda não recebemos respostas.

Com o avanço das ciências, de todas as áreas do conhecimento, o volume, a expansão, ou seja, o crescimento do conhecimento se agiganta, somando a isso, ocorre ainda, a necessidade ou a obrigação - como no caso dos programas de pós-graduação no Brasil - de publicar ou veicular esses conhecimentos do modo mais veloz e econômico que atualmente se utiliza, o meio eletrônico. Não se sabe mais se são mais luzes que se acendem com o conhecer ampliado e especializado ou se estamos sendo guiados para uma nova forma de obscurantismo científico e intelectual. É o conhecimento cientifico intelectual obscurecendo o saber da experiência, da vivência e da vida mesma que se quer viver de forma mais feliz possível. O conhecimento científico substituindo a sabedoria de um saber viver. O Cientista substituindo o Sábio.

Porém, retroceder, ou seja, reduzir o número de pesquisas e publicações não é possível. A única coisa que podemos fazer é manter a esperança de que temáticas de pesquisa e publicação sejam extraídas das necessidades e possibilidades de evolução humana, e não apenas elaborações técnicas para o cumprimento de obrigações com os pontinhos da Capes, por exemplo.

Acreditamos que a Educação Física está começando a sentir essa necessidade, percebível pela ampliação e diversidade de temáticas, muitas vezes, inclusive, bem excêntricas, porém, resultado de vivências e experiências dos pesquisadores, que através destas procuram conhecer, interferir e, especialmente, melhorar práticas e situações de vida.

No presente número foi possível acolher e publicar algumas temáticas de pesquisa centradas neste tipo de necessidades, em práticas regionais, em novas práticas para escola, bem como no conhecimento de funções e valores envolvidos em práticas corriqueiras na escola ou fora dela. Um agradecimento muito especial a todos que nos enviaram trabalhos para a publicação.

Aproveitamos também este momento de fim de ano para desejar a todos um FELIZ NATAL E PRÓSPERO ANO NOVO. 